\title{
Influence of grazing on channel morphology of intermittent streams
}

\author{
MELVIN R. GEORGE, ROYCE E. LARSEN, NEIL K. MCDOUGALD KENNETH W. TATE, JOHN D. GERLACH, \\ JR., AND KENNETH O. FULGHAM
}

Authors are Rangeland Management Specialist, University of California Cooperative Extension, Department of Agronomy and Range Science, University of California, One Shields Ave., Davis, Calif. 95616; Watershed ad Natural Resources Advisor, University of California Cooperative Extension, 2156 Sierra Way Suite C, San Luis Obispo, Calif. 93401; Livestock and Natural Resources Advisor, University of California Cooperative Extension, 328 Madera Ave., Madera, Calif. 93637; Rangeland Watershed Specialist, and Post-Graduate Researcher, respectively, University of California Cooperative Extension, Department of Agronomy and Range Science, University of California, One Shields Ave., Davis, Calif. 95616; and Professor, Rangeland Resources, Humboldt State University, NRS Bldg., Rm 200, Arcata, Calif. 95521.

Abstract

Alteration of stream channel morphology by cattle and associated streambank erosion is a concern on rangeland watersheds. The objective of this study was to determine changes in stream channel morphology in response to 5 grazing treatments applied to 0.4 ha pastures and replicated on 3 intermittent streams at the San Joaquin Experimental Range in the central Sierra Nevada foothills of California. Baseline stream channel morphology parameters were determined along 10 transects in each pasture in June 1994. Seasonal grazing treatments (no grazing, wet season moderate, wet season concentrated, dry season moderate, and dry season concentrated) were repeated annually over 4 years beginning in July 1994. Stream channel morphology parameters were measured annually from 1995-1998. When stream morphological responses were averaged across years, there were no detectable effects of grazing on the parameters measured. Year effects and their interaction with grazing were significant, primarily for stream morphological parameters that included channel depth in their measurement or calculation. Channel depth increased significantly in the ungrazed controls, but did not change due to any grazing treatment. These results indicate that grazing had little effect on the morphology of these bedrock limited, intermittent stream channels.

Key Words: grazing effects, streambank erosion, sediment, annual rangelands, California

Most of California's surface water flows through the state's 6.8 million ha of annual rangelands. Sediment is the most prevalent non-point source pollutant in these surface waters (State Water Resources Control Board Staff 1999). Causes of erosion within these rangelands include natural processes and historic land use, as well as anthropogenic activities such as road construction and livestock production (Lewis et al. 2001). Concerns exist throughout California's Sierra Nevada Mountains (Sierra Nevada

This study was funded by U.S. Environmental Protection Agency Grant No. CR 822209-01-0. The authors wish to thank California State University at Fresno for providing cattle and managing grazing during the study and to personnel at the USDA NRCS Madera Office for assisting in field data collection.

Manuscript accepted 9 Mar. 02.

\section{Resumen}

La alteración de la morfología del canal de la corriente por el ganado y la erosión asociada de la vega del río es una preocupación en las cuencas hidrológicas del pastizal. El objetivo de este estudio fue determinar los cambios en la morfología del canal de la corriente en respuesta a 5 tratamientos de apacentamiento aplicados a potreros de 0.4 ha $y$ repetidos en 3 corrientes intermitentes en la Estación Experimental de Pastizales de San Joaquín al pie de monte de la parte central de la Sierra Nevada de California. Los parámetros de base de la morfología del canal fueron determinados a lo largo de 10 transecto en cada potrero, las mediciones se realizaron en Junio de 1994. Los tratamientos de apacentamiento estacional (no apacentamiento, apacentamiento moderado en la época húmeda, apacentamiento concentrado en la época húmeda, apacentamiento moderado en la época seca, apacentamiento concentrado en la época seca) fueron repetidos anualmente durante 4 años, iniciando en Julio de 1994. Los parámetros de la morfología del canal fueron medidos anualmente de 1995 a 1998. Cuando las respuestas morfológicas del canal se promediaron a través de los años no hubo efectos detectables del apacentamiento en los parámetros medidos. El efecto del año y sus interacciones con el apacentamiento fueron significativas, principalmente para los parámetros morfológicos de la corriente que incluyeron la profundidad del canal en sus medidas o cálculos. La profundidad del canal se incrementa significativamente en los controles sin apacentamiento, pero no cambio debido a algún tratamiento de apacentamiento. Estos resultados indican que el apacentamiento tiene poco efecto en la morfología de estos lechos rocosos de canales de corrientes intermitentes.

Ecosystem Project 1996) and the West (Belsky et al. 1999) that livestock grazing increases stream channel erosion via degradation of streambank vegetation and physical damage to the streambank. Several research and case studies have reported livestock induced streambank erosion leading to channel down cutting or widening (Kauffman and Krueger 1984, McDonald et al. 1991, Hall and Bryant 1995, Sierra Nevada Ecosystem Project 1996). Numerous reviews have identified inherent problems associated with studies examining grazing impacts on stream channel properties including: 1) lack of baseline or pre-treatment data, 2) 
inherent variability between and within watersheds or streams, 3) lack of replication across watersheds or streams, 4) inadequate or ambiguous description of grazing treatments, and 5) slow treatment response time of channel morphological parameters (Kauffman and Krueger 1984, Rinne 1988, Fleischner 1994, Larson et al. 1998, Belsky et al. 1999).

Most of California's foothill rangelands are drained by intermittent streams that only flow during the October to May rainy season. In dry years, many intermittent streams in these rangelands do not flow at all. Studies of livestock impacts on stream channels have focused largely on perennial streams and their associated riparian areas (Kauffman and Krueger 1984) with only a few documenting these impacts on intermittent or ephemeral streams (Marlow et al. 1987, Smith et al. 1993).

The objective of this study was to determine changes in stream channel morphology in response to 2 seasons (wet and dry) and 3 intensities (no grazing, moderate, and concentrated) of grazing. Our first hypothesis was that grazing induced bank erosion along the bedrock limited intermittent streams at the San Joaquin Experimental Range would increase stream channel width at bank full compared to that measured in the baseline year or in the ungrazed channel reaches. Our second hypothesis was that bedload deposition was dynamic and would result in yearly fluctuations in stream channel depth. Changes in stream channel depth and/or width may result in changes in channel cross-sectional area and width-todepth ratio. In an attempt to overcome the problems associated with past livestock stream channel studies, we: 1) collected baseline data, 2) replicated the study on multiple streams, 3) examined defined grazing treatments, and 4) conducted the study over a 5 year period.

\section{Materials and Methods}

\section{Site Description}

This study was conducted at the 1,752 ha San Joaquin Experimental Range (SJER) in Madera County, Calif. $\left(37^{\circ} 05^{\prime} \mathrm{N}, 169^{\circ} 45^{\prime} \mathrm{W}\right)$ which has been a USDA Forest Service research facility since 1935 (Kie 1990). The SJER lies in the lower central Sierra Nevada foothills in the oak savanna vegetation type (Fig. 1). The station has a Mediterranean climate with annual precipitation ranging from 250 to $800 \mathrm{~mm}$ with a mean of 480 $\mathrm{mm}$, coming almost entirely as rainfall between October and April. Mean monthly air temperatures range from $6^{\circ} \mathrm{C}$ in January to $27^{\circ} \mathrm{C}$ in July. Elevation ranges from 213 to $518 \mathrm{~m}$. Soils are derived from granitic rocks, and most are less than 0.76 $\mathrm{m}$ deep. The Ahwahnee series (coarseloamy, mixed thermic Mollic Haploxeralf) is common, covering about $96 \%$ of the SJER. The Visalia soil series (coarseloamy, mixed thermic Pachic Haploxeralf) is found on alluvial or swale sites (Ulrich and Stromberg 1962).

Three intermittent tributaries to Cottonwood Creek were selected for study at the SJER (Fig. 1). Cottonwood Creek is a fourth-order stream that drains into the San Joaquin River just below Friant Dam. During this study, stream flow began in early January following 270 to $360 \mathrm{~mm}$ of rainfall from October-December. Average pre-treatment bankfull width for channels 1, 2, and 3 was 2.54, 2.48, and $3.56 \mathrm{~m}$, respectively. Average channel depth at bankfull was 20 to $25 \mathrm{~cm}$. Within the study site, most channel cross-sectional profiles are "bowl" shaped with bank angles less than 45 degrees, rather than vertical angles. The stream channels do not have undercut banks. The study reaches are low gradient with less than $2 \%$ slope and are Rosgen Class B5 (Rosgen 1996). Stream channels 1,2 , and 3 are 2 to $3 \mathrm{~km}$ apart at elevations ranging from 274 to $411 \mathrm{~m}$ (Fig. 1).

Granite bedrock underlies all 3 stream channels at 2 to $20 \mathrm{~cm}$, thus limiting channel depth and the potential for down-cutting. Bed material deposits on all 3 stream channels is dominated ( $>95 \%)$ by large grained sands from decomposed granite. Run off events cause bedload to be entrained and redeposited downstream. Consequently, the depth of transient bed material, and thus channel depth, within a specific stream reach is inherently dynamic from storm-to-storm and year-to-year. While granite rocks, blue oak (Quercus douglasii Hook \& Arn), interior live oak (Q. wislizenii $\mathrm{DC})$, and other woody vegetation provide some stability, the majority of the streambanks are vegetated by shallow-rooted annual grasses and forbs including: wild oats (Avena fatua L.), soft chess brome (Bromus hordaceus L.), red brome (B. rubens L.), ripgut brome (B. diandrus Roth.), annual fescue (Vulpia myuros L.),

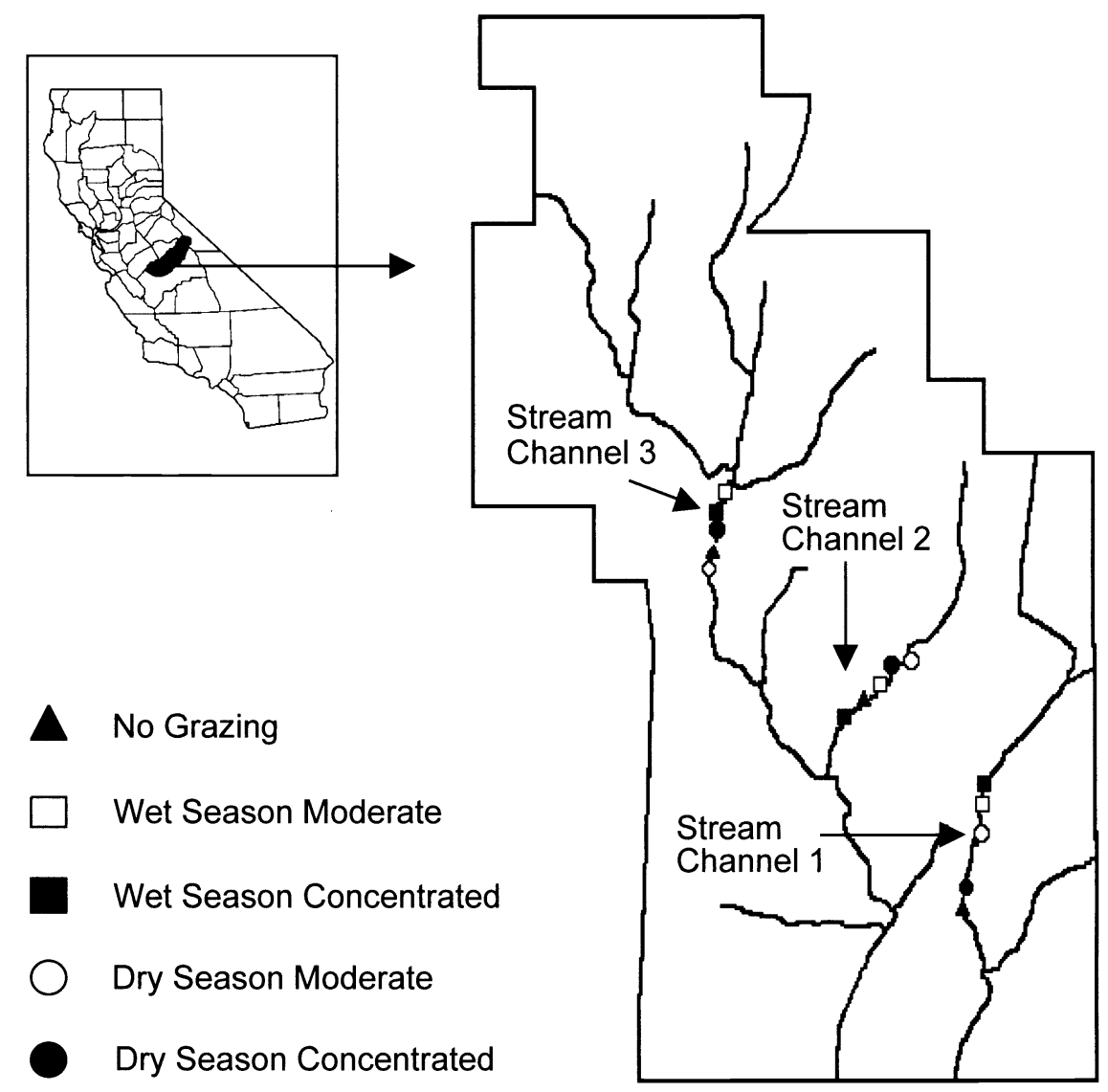

Fig. 1. Location of treatments along stream channels at the San Joaquin Experimental Range in Madera County, Calif. 
broadleaf filaree (Erodium botrys Bertol.), redstem filaree (E. cicutarium L'Her.), popcorn flower (Plagiobothrys notofulvus Gray), and turkey mullein (Eremocarpus setigerous Hook.). There is no riparian vegetation associated with these intermittent stream channels.

\section{Experimental Design}

In this study, the experimental unit was a pasture containing a livestock accessible stream reach of 60 to $70 \mathrm{~m}$ in length. We used replication across 3 stream channels to account for inherent differences among streams. We used randomization and buffers between 5 treatment pastures within each stream channel to minimize possible upstream - downstream effects of treatment position(s). Within each stream, the buffer between treatment pastures ranged from 30 to $200 \mathrm{~m}$. The 3 streams represented blocks in a randomized complete block design to which all treatments were randomly applied. Baseline data was collected in 1994 to establish pre-study conditions and was followed by 4 years of treatment application and data collection to capture variability induced by annual rainfall and runoff dynamics.

\section{Grazing Treatments}

Grazing treatments representing the range of intensity and season found on these rangelands, as well as a non-grazed control, were selected for implementation. Crossbred beef cows were used to apply the grazing treatments. Beginning in the summer of 1994, five grazing treatments were applied to 5 randomly selected 0.4 ha pastures established for this study along each of the 3 streams (Fig. 1). The 0.4 ha pastures were square with a 60 to $70 \mathrm{~m}$ stream segment bisecting each pasture. Portable electric fencing was used to establish the grazed pastures and ungrazed pastures were permanently fenced. Each stream and its five, 0.4 ha pastures was in a different SJER grazing unit. The area of these grazing units is 60 , 110 , and 47 ha, respectively. There were one or more offsite water troughs in each of these grazing units.

The no grazing (NG) treatment consisted of a 0.4 ha permanently fenced exclosure. The wet season moderate grazing (WSM) treatment was applied by grazing during the wet season so that stubble height averaged 5 to $7.5 \mathrm{~cm}$ along the stream channel. The wet season concentration (WSC) treatment consisted of grazing during the wet season so that stubble height along the stream channel averaged less than $5 \mathrm{~cm}$. The dry season moderate grazing (DSM) treatment was applied by grazing during the dry season so that stubble height along the stream channel averaged 5 to $7.5 \mathrm{~cm}$ by 1 October. The dry season concentration (DSC) treatment was applied by grazing during the dry season so that stubble height along the stream channel was less than $5 \mathrm{~cm}$ by 1 October. The livestock concentration treatments (WSC and DSC) were designed to achieve heavy use as is often associated with a feed or watering station. Each grazing treatment was applied to the same pastures in 1994-95, 1995-96, 1996-97, and 1997-98.

Because grazing is not equally distributed within the topographically diverse SJER grazing units, stocking rate is not an accurate descriptor of grazing treatment effect at the stream segment scale. Therefore, treatments were described in terms of stubble height targets along the stream channels. Because forage growth rate varies within the wet season and between years, a flexible system of grazing application was required to maintain stubble height targets. We achieved stubble height targets in the 0.4 ha pastures by opening and closing access to these pastures by the cows grazing in the surrounding grazing unit. At the beginning of the wet season treatments on 1 February, the grazing units surrounding the treatment pastures were stocked at the density of 1 beef cow per 1.6 ha. To maintain stubble height targets during rapid spring growth, additional cows were added to the grazing units in March up to triple the 1 February stock density. Because the small pastures were readily accessible when open, the moderate grazing treatments were easily maintained by opening and closing the pastures as needed during the grazing season. It was occasionally necessary to close the small pastures during the wet season to avoid exceeding the 5 to $7.5 \mathrm{~cm}$ stubble height target in the moderate treatments. The wet season concentrated treatments were never closed during the wet season. To achieve the concentrated grazing treatments, cooked molasses supplement and mineral blocks were placed in the small pasture within $10 \mathrm{~m}$ of the channel to attract cattle into the pasture, thus increasing grazing intensity and trampling along the stream channel. Near the end of the dry season, we closed the DSM treatment pastures and increased the stocking rate by 25 to $50 \%$ for 1 to 3 days to insure that stubble height targets were met in the DSC treatments.

Stubble height was determined by ocular estimate and confirmed with actual measurements as needed. Stubble height was estimated weekly in the pastures that were being treated that season. Target stubble heights for moderate grazing were achieved throughout the 0.4 ha pasture. Stubble height targets for the concentrated treatments were achieved along a $10 \mathrm{~m}$ zone on either side of the stream channel.

Dry season grazing treatments (DSM and DSC) were applied between 1 July and 1 October, a period of little or no rainfall. Typically, the wet season begins in late October or early November and ends by 1 May. This period includes the slow winter growth period and all of the rapid spring growth period of the growing season (George et al. 2001). The soil profile is usually saturated by early January. Wet season treatments (WSM and WSC) were applied starting on 1 February and maintained until surface soil moisture was depleted at the end of the growing season between 15 April and 1 May each year.

\section{Stream Channel Measurements}

To determine changes in stream channel morphology, we measured width and depth along stream channel cross-sections which allowed us to calculate various morphological parameters. The width parameters were used to detect streambank erosion. Depth parameters were used to detect annual fluctuations in channel bedload.

Stream morphological measurements were recorded during the first week of June at the beginning of the dry season starting with the baseline year in 1994. Channel cross sections were measured using methods outlined by Bauer and Burton (1993). For each stream reach within a pasture, 10 permanent cross-sectional transects, 6.1 to $9.1 \mathrm{~m}$ long, were placed perpendicular to the stream channel at a distance of 1 to 1.5 times the channel width apart (Fig. 2). The transects were marked with permanent stakes and referenced to a permanent benchmark. Stream elevation was determined every $15 \mathrm{~cm}$ along the transect using a stretched tape, laser level, and stadia rod. For each transect, width at bankfull (W), distance from the left permanent stake to right and left bank at bankfull height, maximum depth, and depth every $15 \mathrm{~cm}$ were measured (Fig. 2). Cross-sectional area (A), channel average depth (A/W), and width-to-depth ratio [W/(A/W)] were calculated. Pasture averages for each morphological parameter were calculated from the 10 transects in each pasture. Cross-sectional area of the channel was determined using bankfull elevations following the methods of Rosgen (1996). Elevation and position readings of the permanent end stakes were checked with benchmark elevations each year. 


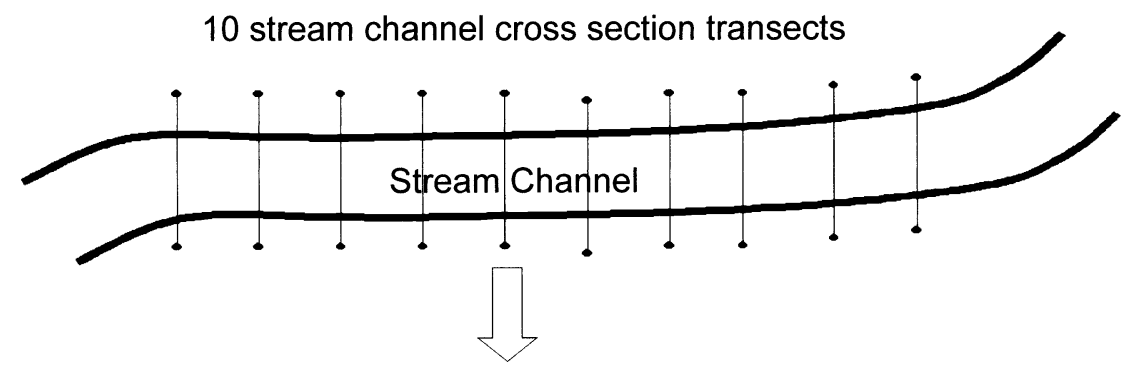

Transect

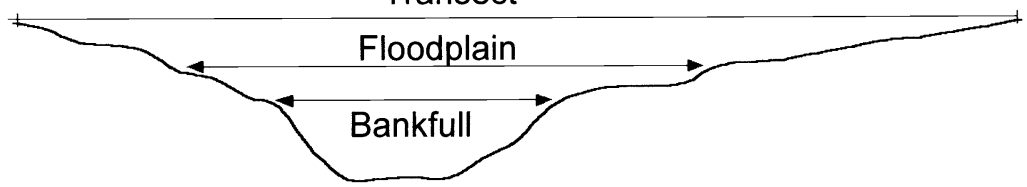

Fig. 2. Layout of stream channel cross-sectional transects.

\section{Data Analysis}

Multivariate repeated measures analysis techniques were used to determine how 7 stream morphological parameters were affected by grazing treatment, year, and year $x$ grazing interactions. Profile contrasts were then used to compare successive year-to-year differences among the grazing treatments (Tabachnick and Fidell 1989). Finally, pair-wise comparisons (Khattree and Naik 1999) were used to test for differences between the no grazing treatment and the moderate and concentrated grazing treatments following the 1996-97 water year characterized by above average flow events. All analyses were conducted using SAS Release 6.12 for Open VMS (SAS Institute Inc. 1996).

\section{Results and Discussion}

When stream morphological responses to grazing treatments were averaged across years, there were no detectable effects on channel width, distance to right and left bank, maximum depth, mean depth, cross-sectional area, and width-todepth ratio (Table 1). There was a significant year effect for the depth-based parameters (maximum depth, mean depth, cross sectional area, and width-to-depth ratio). Examination of the yearly means for each treatment (Fig. 3) revealed large changes in several of the depth-based parameters from 1996 to 1997 . The year $x$ grazing interaction was significant for the depth-based parameters and for left bank distance when using Roy's maximum root test in the MANOVA. While Roy's test is weaker than other MANOVA tests of significance, other less sensitive (more restrictive) tests increase the risk of overlooking the potential for grazing damage. The profile contrasts indicate that the grazing treatments accounted for significant differences in maximum depth from 1996 to 1997. Examination of the proportional changes in maximum depth and mean depth (Fig. 4) revealed that channel depth in the no grazing (NG) treatment increased over the four years of the experiment. This contributed to the significant pairwise comparison between the wet season moderate grazing (WSM) and the NG treatments.

Channel width and distance to right bank did not change in response to the grazing treatments. Distance to left bank was significant for the year $\mathrm{x}$ grazing interaction. There have been conflicting reports on the relationship between grazing along stream channels and sediment loss from streambanks. Buckhouse et al. (1981), Smith et al. (1993), and Kondolf (1993) detected no significant streambank erosion due to grazing. Conversely, several studies comparing exclosures to grazed areas report significant sediment losses from grazed streambanks (Gunderson

Table 1. Summary of multivariate repeated measures analysis of variance results after Dunn-Šidák familywise adjustments for multiple comparisons.

\begin{tabular}{|c|c|c|c|c|c|c|c|}
\hline & \multirow{2}{*}{$\begin{array}{l}\text { Graze } \\
\text { (G) }\end{array}$} & \multirow{2}{*}{$\begin{array}{l}\text { Year } \\
(Y)\end{array}$} & \multirow{2}{*}{$Y \times G$} & \multicolumn{3}{|c|}{ Profile Analysis ${ }^{1}$} & \multirow{2}{*}{$\frac{\text { Pairwise }^{1}}{1997}$} \\
\hline & & & & $95-96$ & $96-97$ & $97-98$ & \\
\hline Cross-sectional Area & n.s. & ** & * & n.s. & n.s. & n.s. & n.s. \\
\hline Width & n.s. & n.s. & n.s. & n.s. & n.s. & n.s. & n.s. \\
\hline Width-to-Depth Ratio & n.s. & $* *$ & $*$ & n.s. & $\mathrm{L}$ & n.s. & n.s. \\
\hline Maximum Depth & n.s. & ** & ** & n.s. & $\mathrm{L}, \mathrm{G}$ & n.s. & n.s. \\
\hline Mean Depth & n.s. & $* * *$ & * & $\mathrm{L}^{2}$ & $\mathrm{~L}$ & n.s. & WSM \\
\hline Right Bank Distance & n.s. & n.s. & n.s. & n.s. & n.s. & n.s. & n.s. \\
\hline Left Bank Distance & n.s. & n.s. & ** & n.s. & n.s. & $\mathrm{G}$ & n.s. \\
\hline
\end{tabular}

$* \mathrm{p} \leq 0.05 ; * * \mathrm{p} \leq 0.01 ; * * * \mathrm{p} \leq 0.001$.

${ }^{1}$ For $\alpha=0.10$, a Dunn Sidak family-wise significant $\mathrm{p}$ value must be $<0.015$ for the profile and pairwise contrasts (Maxwell and Delaney 1990, Sokal and Rohlf 1995).

${ }^{2} \mathrm{~L}$ indicates a significant linear rend, $\mathrm{G}$ indicates a significant grazing treatment effect, ans WSM inicates a significant wet season moderate grazing treatment effect.
1968, Behnke and Zarn 1976, Hedee 1977, Dahlem 1979, Duff 1979, Kauffman et al. 1983, Platts and Nelson 1985, Elmore and Beschta 1987, Marlow et al. 1987, Clary and Webster 1989, 1990, Platts 1991, Myers and Swanson 1994, Swanson and Myers 1994, Trimble 1994). Several of these studies reported that increased channel width was the result of sloughing of undercut banks. The stream channel banks in this study were not undercut and could not achieve this form under any grazing scheme due to substrate type (sand) and dominance by shallow rooted annual vegetation. While most of these studies compared an exclosure to a grazed area, a few studies compared ungrazed areas to several treatments. Siekert et al. (1985) detected changes in stream channel cross-sectional area due to summer and fall grazing treatments along an ephemeral stream in Wyoming. Applying several seasonal grazing treatments, Marlow et al. (1987) detected changes in the stream channel profile due to grazing and trampling of streambanks when streambank soils were moist during the early summer.

We observed grazing and trampling along the stream channel bank by cattle in the treated pastures, yet detected no change in channel width at bankfull. Fine textured and wet streambank soils have been shown to be a factor in vulnerability to erosion (Wolman 1959, Hooke 1979, Marlow and Pogacnik 1985, Marlow et al. 1987, Clary and Webster 1990). The well drained course sands in our study lack the fine particle sizes and have a low water holding capacity which may reduce their vulnerability to streambank erosion. Trimble and Mendel (1995) suggested that watersheds subjected to high intensity, long duration storms generating high stream discharges were more vulnerable to streambank erosion than watersheds that receive relatively equitable flow from 

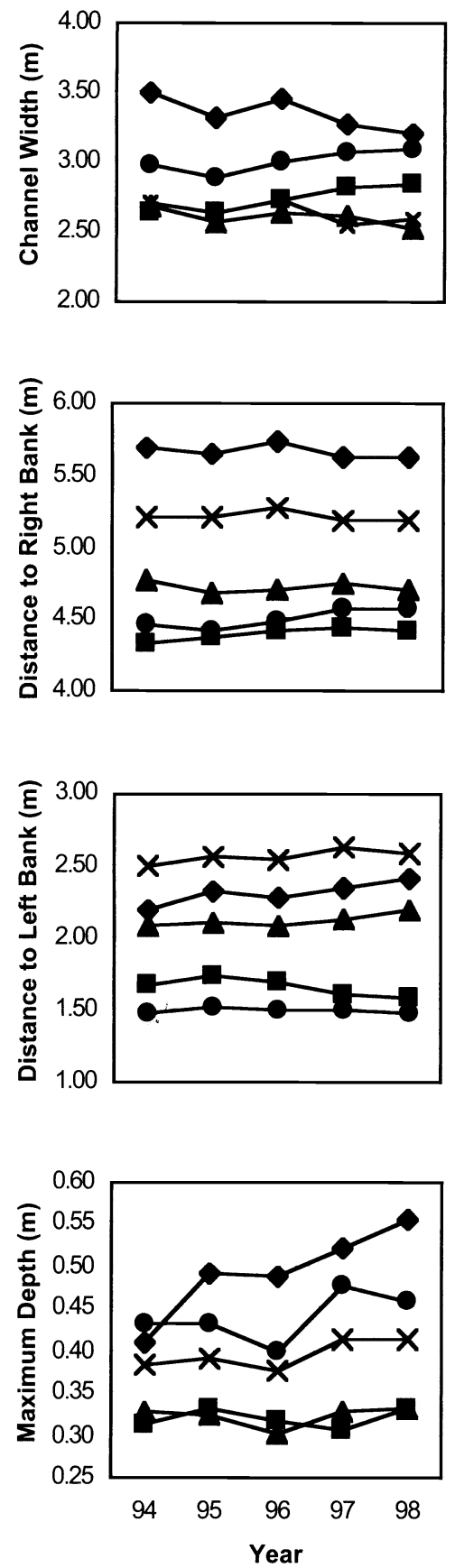

Fig. 3. Yearly treatment means for channel width, distance to right and left bank, maximum depth, mean depth, cross-sectional area, and width-to-depth-ratio.

snowmelt. During our study, one or more high stream discharges occurred each year lasting for only a few hours during and following a storm. Lack of high intensity rainfall and runoff early in the rainy season may reduce streambank erosion. While intense grazing and trampling can leave unvegetated loose soil at the beginning of the rainy season, low intensity rainfall which is characteristic of the early rainy season results in germination and seedling establishment that stabilizes
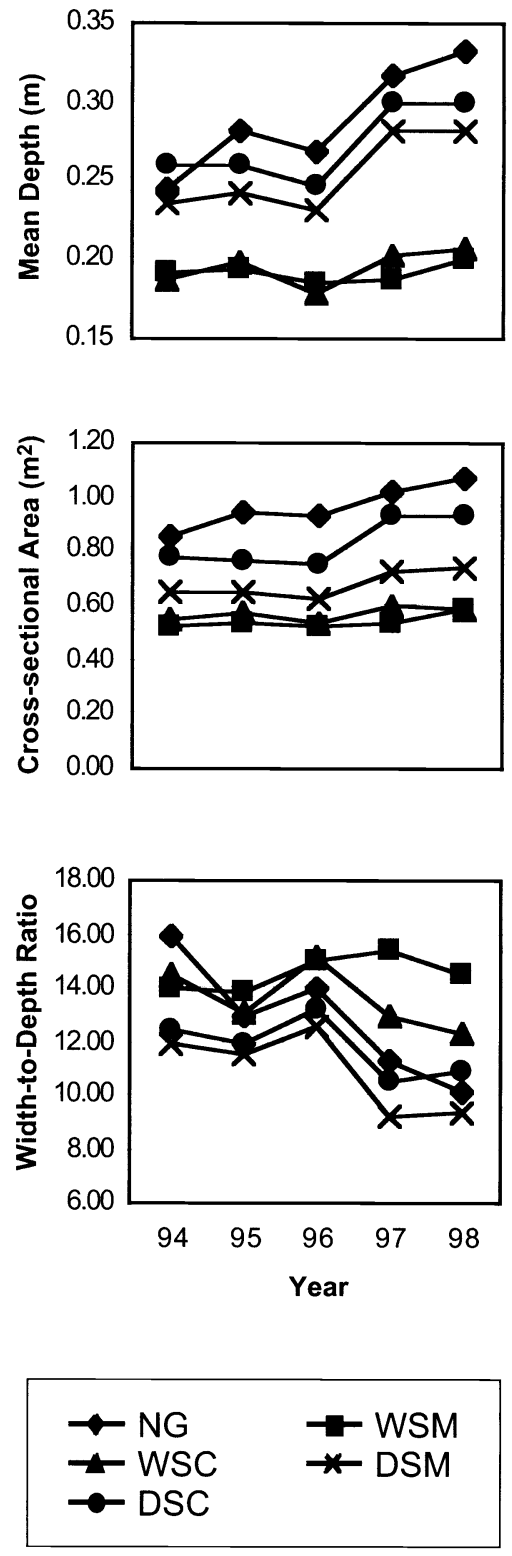

grazed and trampled soil surfaces before periods of more intense rainfall begin.

Just as grazed stream channels are expected to widen when subjected to grazing, stream channels that are protected from grazing are expected to narrow (McDowell and Magilligan 1997). While not significant, the results of this study suggest that the stream channels in the controls may be narrowing (Fig. 3). Kondolf (1993) reports that recent exclosures (less than 4 years old) have not had
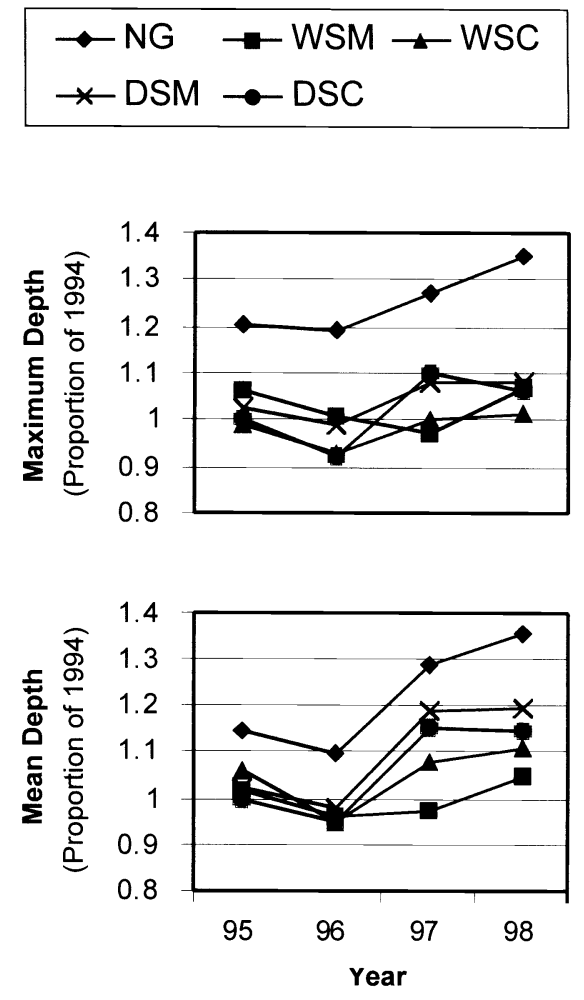

Fig. 4. Yearly proportional change in maximum and mean depth.

time to trap sediment and build bank that results in channel narrowing while differences were more pronounced in older exclosures. Magilligan and McDowell (1997) suggest that streams that lack fine sediment and woody vegetation may take longer to show channel adjustment to protection from grazing. However, the woody vegetation that traps sediment during the bank building process is not present and not known to be within the potential of these oak woodland stream channels.

Seasonal and annual variation in precipitation and resulting run-off could account for the large year effect detected in this study. The 1996-97 rainfall year was characterized by above average stream flow. We observed significant movement of bed material during one or more annual high flow events, usually in January or February, which would have a significant annual effect on channel depth parameters. The significance of year in the results of this study make it difficult to isolate the effect of annual stream flow dynamics from grazing effects on stream channel morphology. We would suggest that stream flow is the largest potential confounder in testing for the effect of grazing on streambank or stream channel morphology. Roath (1980) reported that the actions of streamflow rather than livestock tram- 
pling was the cause of streambank erosion in an eastern Oregon study. Buckhouse et al. (1981) reported that most bank cutting was associated with over-winter periods when ice flows and high flow events occurred.

Channel deepening in the control treatments indicates that there was a loss of bedload sediment from the control reaches. Treatment randomization within each stream (block) resulted in the controls being placed at the lowest or next to lowest pasture in the sequence of 5 pastures along each stream. One might expect channel depth in the controls to become shallower if they were influenced by delivery of sediment from upstream grazed treatments, but not for the channel to deepen. While there was no significant change in channel width, Figure 3 suggests a trend toward channel narrowing that may have resulted in increased stream power that could have eroded bedload sediment in the control pastures.

On these stream channels, it was difficult to interpret grazing effects using standard stream morphology parameters (width, depth, area, and width-to-depth ratio). Width did not change significantly and depth parameters were more a reflection of annual flow and bedload dynamics than grazing influences. Distance to left or right bank, an absolute measure from a permanent point, may be more responsive to grazing effects than the standard stream morphology width parameter because changes on one bank may compensate for changes on the opposite bank. We detected a small, weakly significant, change in distance to left bank for the year $\mathrm{x}$ grazing interaction during this 5 year study. Over a longer period, if grazing effects accumulated sufficiently, an absolute measure such as distance to right and left bank or distance to cut bank (Buckhouse et al. 1981) may be more responsive than channel width.

\section{Conclusions}

In conclusion, we detected no significant streambank erosion, thus we must reject our hypothesis that grazing increases width in these bedrock limited stream channels. We detected a significant increase in depth in the control treatments. Additionally, we found a significant year effect on morphological parameters that included depth in their measurement or calculation, supporting our hypothesis that annual stream flow dynamics have a large effect on depth of the stream channels we studied. The large year effect and weaker year $\mathrm{x}$ grazing effect on stream morphology confirms the need for long-term studies to separate natural variation in stream morphological parameters from those caused by land management activities.

\section{Literature Cited}

Bauer, Stephen B. and Timothy A. Burton. 1993. Monitoring protocols to evaluate water quality effects of grazing management on western rangeland streams. U.S. Environ. Prot. Agency, Washington, D.C.

Behnke, R.J. and M. Zarn. 1976. Biology and management of threatened and endangered western trouts. USDA For. Serv. Gen. Tech. Rep. RM-28.

Belsky, A.J., A. Matzke, and S. Uselman. 1999. Survey of livestock influences on stream and riparian ecosystems in the western United States. J. Soil and Water Consv. 54:419-431.

Buckhouse, J.C., J.M. Skovlin, and R.W. Knight. 1981. Streambank erosion and ungulate grazing relationships. J. Range. Manage. 34:339-340.

Clary, W.P. and B.F. Webster. 1989. Managing grazing of riparian areas on the intermountain region. USDA For. Serv. Gen. Tech. Rep. INT-263.

Clary, W.P. and B.F. Webster. 1990. Recommended riparian grazing practices, $\mathrm{p}$. 75-81. In: Proc. XXI Int. Erosion Control Assoc. Washington, D.C.

Dahlem, E.A. 1979. The Mahogany Creek watershed-with and without grazing, $\mathrm{p}$. 31-35. In: O.B. Cope (ed.), Forum: Grazing and riparian/stream ecosystems. Trout Unlimited, Vienna, Virg.

Duff, D.A. 1979. Riparian habitation recovery on Big Creek, Rich County, Utah: A summary of 8 years of study, p. 91-92. In: O.B. Cope (ed.), Forum: Grazing and riparian/stream ecosystems. Trout Unlimited, Vienna, Virg.

Elmore, W. and R.L. Beschta. 1987. Riparian areas: perceptions in management. Rangelands 9: 260-265.

Fleischner, Thomas L. 1994. Ecological costs of livestock grazing in western North America. Conserv. Bio. 8:629-644.

George, Mel, Jim Bartolome, Neil McDougald, Mike Connor, Charles Vaughn, and Gary Markegard. 2001. Annual range forage production. Publication 8018. Univ. Calif. Div. Agr. and Natur. Resour., Oakland, Calif.

Gunderson, D.R. 1968. Flood plain use related to stream morphology and fish populations. J. Wildlife Manage. 32:507-514.

Hall, Frederick C. and Larry Bryant. 1995. Herbaceous stubble height as a warning of impending cattle grazing damage to riparian areas. USDA For. Serv. Gen. Tech. Rep. PNW-GTR-362.
Hedee, Blanchard H. 1977. Case study of a watershed rehabilitation project: Alkali Creek, Colorado. USDA For. Serv. Res. Pap. RM-189.

Hooke, J.M. 1979. An analysis of the processes of river bank erosion. J. Hydrol. 42:39-62.

Kauffman, J.B. and W.C. Krueger. 1984. Livestock impacts on riparian ecosystems and streamside management implications: A review. J. Range Manage. 37: 430-438.

Kauffman, J.B., W.C. Krueger, and M. Vavra. 1983. Impacts of cattle on streambanks in northeastern Oregon. J. Range Manage. 36: 683-685.

Khattree, Ravindra and Dayanand N. Naik. 1999. Applied Multivariate Statistics, $2^{\text {nd }}$ ed. SAS Institute Inc., Cary, N.C.

Kie, John G. 1990. San Joaquin Experimental Range, p. 38-43. In: Neil H. Berg (tech. coord.), Experimental forests and ranges: Field research facilities of the Pacific Southwest Research Station. Gen. Tech. Rep. PSW 119.

Kondolf, G. Mathias. 1993. Lag in stream channel adjustment to livestock exclosure, White Mountains, Calif. Restoration Ecol. 1:226-230.

Larsen, Royce, William C. Krueger, Melvin R. George, Mack R. Barrington, John C. Buckhouse, and Douglas E. Johnson. 1998. Viewpoint: Livestock influences on riparian zones and fish habitat: Literature classification. J. Range Manage. 51:661-554.

Lewis, D.J., K.W. Tate, J.M. Harper, and J. Price. 2001. Survey identifies sediment sources in North Coast rangelands. Calif. Agr. 55:32-38.

Marlow, C. B. and T. M. Pogacnik. 1985. Time of grazing and cattle induced damage to streambanks, p. 270-284. USDA For. Serv. Gen. Tech. Rep. RM-120.

Marlow, Clayton B., Thomas M. Pogacnik, and Shannon D. Quinsey. 1987. Streambank stability and cattle grazing in southwestern Montana. J. Soil and Water Consv. 42:291-296.

Maxwell, S.E. and H.D. Delaney. 1990. Designing experiments and analyzing data. Wadsworth Publ., Belmont, Calif.

McDonald, Lee H., Alan W. Smart, and Robert C. Wissmar. 1991. Monitoring guidelines to evaluate effects of forestry activities on streams in the Pacific Northwest and Alaska. EPA 910/9-91-001. Water Division, Region 10, U.S. Environ. Prot. Agency, Seattle, Wash.

Magilligan, Francis J. and Patricia F. McDowell. 1997. Stream channel adjustments following elimination of cattle grazing. J. Amer. Water Res. Assoc. 33:867-877.

McDowell, Patricia F. and Francis J. Magilligan. 1997. Responses of stream channels to removal of cattle grazing disturbance: Overview of western U.S. exclosure studies, p. 469-475. In: S.Y. Wang (ed.), Proc. management of landscapes disturbed by channel incision. Univ. Mississippi, Oxford, Miss. 
Myers, T. and S. Swanson. 1994. Grazing effects on pool forming features in central Nevada, p. 235-244. In: R. A. Marston and V.R. Hasfurther (eds.), Effects of humaninduced changes on hydrologic systems. Amer. Water Res. Assoc.

Platts, W.S. and R.L. Nelson. 1985. Impacts of rest-rotation grazing on streambanks in forested watersheds in Idaho. North Amer. J. Fish. Manage. 5:547-556.

Platts, W.S. 1991. Livestock grazing, p. 389-423. In: W.R. Meehan (ed.), Influences of forest and rangeland management on salmonid fishes and their habitats. Amer. Fish. Soc. Spec. Pub. 19. Bethesda, Md.

Rosgen, Dave. 1996. Applied river morphology. Wildland Hydrology. Pagosa Springs, Colo.

Rinne, John N. 1988. Grazing effects on stream habitat and fishes: Research design considerations. N. Amer. J. Fish. Manage. 8:240-247.

Roath, L.R. 1980. Cattle grazing and behavior on a forested mountain range and their relationship to acute dietary bovine pulmonary emphysema. Ph.D. Thesis. Oregon State Univ., Corvallis, Ore.
SAS Institute Inc. 1996. SAS Release 6.12 for Open VMS. Cary, N.C.

Sierra Nevada Ecosystem Project. 1996. Status of the Sierra Nevada: Assessment summaries and management strategies. Wildland Resources Center Rep. No. 36. Univ. Calif., Davis, Calif.

Siekert, R.E., Q.D. Skinner, M.A. Smith, J.L. Dodd, and J.D. Rodgers. 1985. Channel response of an ephemeral stream in Wyoming to selected grazing treatments, $\mathrm{p}$. 276-278. In: R.R. Johnson et al. (Tech Coord.), Riparian ecosystems and their management: reconciling conflicting uses. USDA For. Serv. Gen. Tech Rep. RM-120.

Smith, Michael A., Jerrold L. Dodd, Quentin D. Skinner, and J. Daniel Rogers. 1993. Dynamics of vegetation along and adjacent to an ephemeral channel. J. Range Manage. 46:56-64.

Sokal, R.R. and F.J. Rohlf. 1995. Biometry. W. H. Freeman and Company, New York, N.Y.

State Water Resources Control Board Staff. 1999. The 1998 California 305(b) report on water quality. State Water Resources Control Board, Sacramento, Calif.
Swanson S. and T. Myers. 1994. Streams, geomorphology, riparian vegetation, and feedback loops; thoughts for riparian grazing management by objectives, p. 255-264. In: R.A. Marston and V.R. Hasfurther (ed.), Effects of human-induced changes on hydrologic systems. Amer. Water Res. Assoc.

Tabachnick, B.G. and L.S. Fidell. 1989. Using multivariate statistics, $2^{\text {nd }}$ edition. Harper Collins, New York, N.Y.

Trimble, S.W. 1994. Erosional effects of cattle on streambanks in Tennessee, U.S.A. Earth Surf. Process. Landforms 19:451-464.

Trimble, Stanley W. and Alexandra C. Mendel. 1995. The cow as a geomorphic agent-A critical review. Geomorphology 13:233-253.

Ulrich, Rudolph and Leslie K. Stromberg. 1962. Madera area soil survey. USDA Soil Conserv. Serv.

Wolman, M.G. 1959. Factors influencing erosion of a cohesive river bank. Amer. J. Sci. 257:204-216. 